\title{
Metastatic Breast Carcinoma
}

National Cancer Institute

\section{Source}

National Cancer Institute. Metastatic Breast Carcinoma. NCI Thesaurus. Code C153238.

A carcinoma that arises from the breast and has metastasized to another anatomic site. 